\title{
Research on iron ore tailing improving Compressive Strength of Alkali- activated Slag Foamed concrete
}

\author{
Li Junzhe ${ }^{1, a}$, Tian Yuze ${ }^{1, a}$, Sun Qiubai ${ }^{1, a}$ and Pan Changsheng ${ }^{2, a}$ \\ ${ }^{1}$ University of science and technology Liaoning, Anshan City, Liaoning Province, China. \\ ${ }^{2}$ Liaoning Jijia Energy saving wall equipment co., LTD. Anshan City, Liaoning Province, China \\ atianyuzhe@163.com
}

Keywords: Iron ore tailing powder; Concrete; Mineral waste residue

Abstract. The research on whether can iron ore tailing improve the compressive strength of alkaliactivated slag foaming concrete is conducted. The experiment shows that too little or too much powder from iron ore tailing will reduce the compression strength of alkali activated slag concrete, when powder from iron ore tailing achieving optimal amount, the compression strength of alkali activated slag concrete will be obviously improved, with the further increase of iron tailing powder content, Compressive Strength of alkali activated slag foaming concrete will decrease; with decreasing of the particle size of powders from iron ore tailing, alkali-activated slag foaming concrete compressive strength will increase gradually, with the increasing of fineness, its compressive strength also increases.

\section{Introduction}

Alkali-activated slag cement is a type of binding material using basic compound of alkali metal to activate slag, and alkali-activated slag concrete based on which has many excellent performance, such as rapid hardening high strength, low heat of hydration, good durability, low energy consumption and so on. Instead of cement concrete, which saves a lot of resource and energy. Various aggregate could be used, such as recycle aggregate, common aggregate and other aggregate which mud content a bit high. It is a new type of environment friendly concrete. ${ }^{[1-3]}$

Along with the development of mineral resource, people pay more and more attention to tailing pollution. The composition of iron ore tailing in our country is complicated and various, which has uneven distribution and large amount of emissions. The tailing should be disposed in time, otherwise, they would occupy land,pollute environment and even influence peoples' lives. Nowadays, how to make the tailing meeting the requirements of sustainable development and keeping coordinated development with environment became the target of the tailing development.

Foamy concrete is a kind of green environmental protection material,which is an organic whole has unique advantage of incorporating new wall material and heat-insulate into . Because of the character of light-weight, high- strength, low heat conductivity factor, thermal insulation, fire resistance,moisture proofing and sound insulation,which is widely used in modern architectures. The foamed concrete wall, which made of iron ore tailing and alkali-activated slag cement as cementitious material, have many advantages of high-weight, low heat conductivity factor, higher resistance, simple technology and little investment. It is a new building material with a great development prospect, which should be developed and disseminated with great efforts. ${ }^{[4]}$

\section{Experimental Section}

\section{Main Raw Materials}

Slag powder(specific surface area $>400 \mathrm{~m} 2 / \mathrm{g}$ ), S95, ansteel slag development company.

Iron ore tailing(Chemical Constituents shown in table 1), Gong changling, Liaoyang.

Ordinary portland cement(PO.42.5), Liaoyang Tianrui Cement Co. Ltd.

Activator, self-made.

Admixture, self-made. 
Table 1 Chemical Constituents of iron ore tailing (\%)

\begin{tabular}{cccccccccc}
\hline $\mathrm{CaO}$ & $\mathrm{SiO}_{2}$ & $\mathrm{Al}_{2} \mathrm{O}_{3}$ & $\mathrm{Fe}_{2} \mathrm{O}_{3}$ & $\mathrm{MgO}$ & $\mathrm{SO}_{3}$ & $\mathrm{~K}_{2} \mathrm{O}$ & $\mathrm{Na}_{2} \mathrm{O}$ & $\mathrm{Cl}^{-}$ & Loss \\
\hline 4.55 & 63.75 & 4.77 & 14.46 & 3.68 & 0.04 & 0.82 & 0.63 & 0.012 & 5.53 \\
\hline
\end{tabular}

\section{Experimental Equipment}

Shenyang Julin machinery Company constant compression testing machine for Cement.

\section{Experimental Methods}

Mix calculation: Prepared slag powder, iron ore tailing, ordinary portland cement, admixture ect., according to a certain proportion. Beat the mixture until smooth. Mix proportions of alkali-activated slag foamed concrete (AAFC)was shown in table 2.

Test sample preparing: Mix premix, foaming agent and as much of the water as you need to make a well-distributed slurry. Pouring into a mold, and standing foaming for hours.Take off the mold until its shape stabilized.Make its size into $100 \mathrm{~mm} \times 100 \mathrm{~mm} \times 100 \mathrm{~mm}$. The density was depend on the proportion of agent.

Compressive strength test: Test compressive strength after 3, 7 and 28 days.

Table 2 Mix proportions of Alkali-activated Slag Foamed concrete

\begin{tabular}{cc}
\hline composition & content $(\%)$ \\
\hline slag powder & $25-65$ \\
iron ore tailing & $15-55$ \\
ordinary portland cement & $15-35$ \\
activator & $5-10$ \\
Admixture & $1-5$ \\
foaming agent & $3 \%-5 \%$ \\
water & water-cement ratio \\
& $0.35-0.45$ \\
\hline
\end{tabular}

\section{Characterization}

The the specimen of apparent density and compressive strength accorded with JG237 standard. Compression testing machine accorded with GB/T10294 standard.

\section{Results and Discussion}

\section{Influence of different apparent density on compressive strength}

The influence of different apparent density on compressive strength was studied, while the components of alkali-activated slag foamed concrete at a given blending volume.

Listed in Table 3 the compressive strength of Aalkali-activated slag foamed concrete increases on account of the hydration reaction is in process with prolonging curing time. At the same time, apparent density increases gradually play an important role in adding the compressive strength. When slag powder proportion reached $45 \%$, iron ore tailing proportion reached $35 \%$, ordinary portland cement proportion reached 15\%, 28 days compressive strength of alkali-activated slag foamed concrete(apparent density is $500 \mathrm{Kg} / \mathrm{m} 3$ ) can reached $2.59 \mathrm{MPa}$ in standard curing condition. 
Table 3 Influence of different apparent density on compressive strength

\begin{tabular}{ccccccc}
\hline \multirow{2}{*}{$\begin{array}{c}\text { apparent } \\
\text { density } \\
\left(\mathrm{Kg} / \mathrm{m}^{3}\right)\end{array}$} & \multicolumn{3}{c}{ proportion $(\%)$} & \multicolumn{3}{c}{$\begin{array}{c}\text { compressive strengths lag powder } \\
(\mathrm{MPa})\end{array}$} \\
\cline { 2 - 7 } & $\begin{array}{c}\text { slag } \\
\text { powder }\end{array}$ & $\begin{array}{c}\text { iron ore } \\
\text { tailing }\end{array}$ & $\begin{array}{c}\text { ordinary } \\
\text { portland } \\
\text { cement }\end{array}$ & $3 \mathrm{~d}$ & $7 \mathrm{~d}$ & $28 \mathrm{~d}$ \\
\hline 250 & 45 & 35 & 15 & 0.17 & 0.19 & 0.25 \\
300 & 45 & 35 & 15 & 0.26 & 0.34 & 0.45 \\
350 & 45 & 35 & 15 & 0.66 & 0.78 & 0.97 \\
400 & 45 & 35 & 15 & 1.14 & 1.27 & 1.58 \\
450 & 45 & 35 & 15 & 1.57 & 1.86 & 2.10 \\
500 & 45 & 35 & 15 & 1.84 & 2.13 & 2.59 \\
\hline
\end{tabular}

Influence of iron ore tailing content on compressive strength of AAFC

The influence of different proportion of iron ore tailing and slag powder on compressive strength was investigated, with the apparent density of alkali-activated slag foamed concrete is 500 $\mathrm{Kg} / \mathrm{m} 3$. and ordinary portland cement proportion is $15 \%$.

Table 4 Influence of iron ore tailing content on compressive strength of AAFC

\begin{tabular}{ccccccc}
\hline $\begin{array}{c}\text { apparent } \\
\text { density } \\
\left(\mathrm{Kg} / \mathrm{m}^{3}\right)\end{array}$ & $\begin{array}{c}\text { proportion }(\%) \\
\text { iron ore } \\
\text { tailing }\end{array}$ & slag powder & $\begin{array}{c}\text { ordinary } \\
\text { portland } \\
\text { cement }\end{array}$ & $3 \mathrm{~d}$ & $7 \mathrm{~d}$ & $28 \mathrm{~d}$ \\
\hline \multirow{2}{*}{500} & 15 & 65 & 15 & 1.26 & 1.53 & 1.88 \\
& 25 & 55 & 15 & 1.47 & 1.87 & 2.28 \\
& 35 & 45 & 15 & 1.84 & 2.13 & 2.59 \\
& 45 & 35 & 15 & 0.81 & 1.15 & 1.72 \\
& 55 & 25 & 15 & 0.33 & 0.44 & 0.65 \\
\hline
\end{tabular}

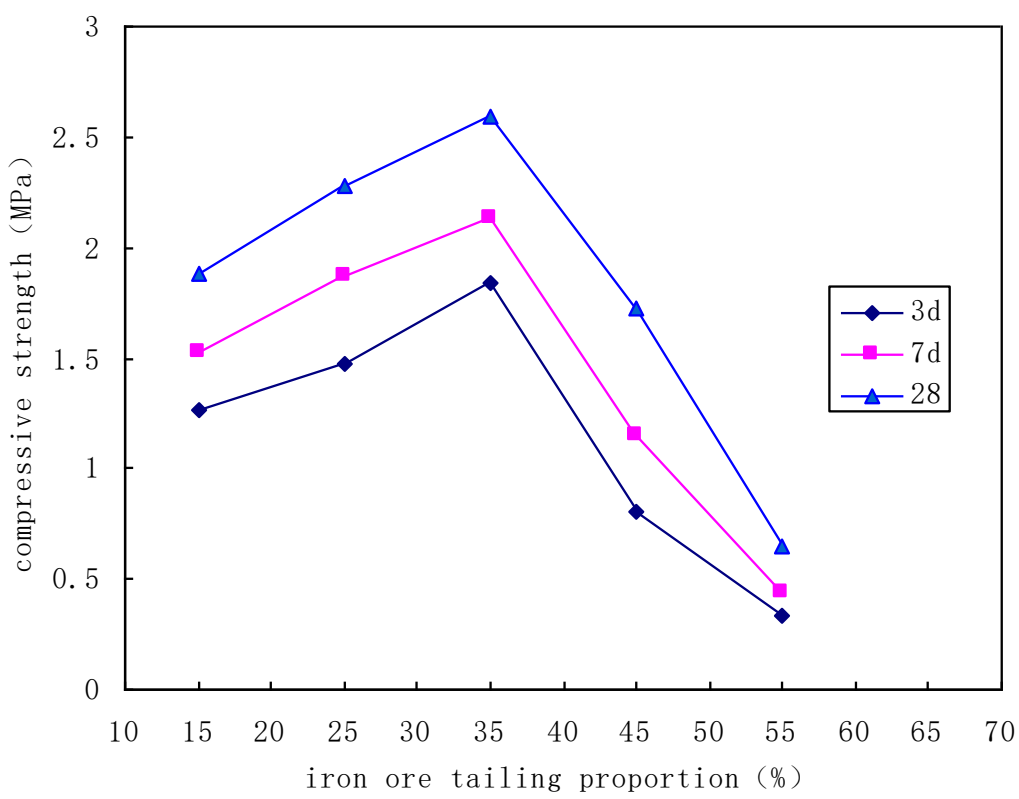

Figure 1 Influence of iron ore tailing content on compressive strength of AAFC 
As shown in Table 4 and Figure, the compressive strength of alkali-activated slag foamed concrete increases gradually when the iron ore tailing content rises from $15 \%$ to $35 \%$, but loss obviously when the iron ore tailing content rises from $35 \%$ to $55 \%$.

Iron ore tailing particles play a role in increases the compressive strength of alkali-activated slag foamed concrete, when it were well-dispersed in matrix with a proper proportion . Matrix interface was destroyed as the iron ore tailing particles were increased continuously, that lead to the decline of the binding power between the iron ore tailing particles and matrix. Compressive strength loss of alkali-activated slag foamed concrete was attributed to iron ore tailing particles uneven dispersing that result in segregation.

\section{Influence of special surface of iron ore tailing on compressive strength of AAFC}

The influence of different fineness of iron ore tailing on compressive strength was investigated, with the apparent density of alkali-activated slag foamed concrete is $500 \mathrm{Kg} / \mathrm{m}^{3}$, and iron ore tailing proportion is $15 \%$.

Table 5 Influence of fineness of iron ore tailing on compressive strength of AAFC

\begin{tabular}{ccccc}
\hline \multirow{2}{*}{$\begin{array}{c}\text { apparent } \\
\text { density } \\
\left(\mathrm{Kg} / \mathrm{m}^{3}\right)\end{array}$} & $\begin{array}{c}\text { fineness of } \\
\text { iron ore } \\
\text { tailing } \\
(\text { mesh })\end{array}$ & $3 \mathrm{~d}$ & $7 \mathrm{~d}$ & $28 \mathrm{~d}$ \\
\cline { 3 - 5 } & 50 & 1.60 & 1.82 & 2.18 \\
500 & 100 & 1.73 & 1.94 & 2.37 \\
& 150 & 1.97 & 2.19 & 2.42 \\
& 200 & 2.01 & 2.33 & 2.56 \\
\hline
\end{tabular}

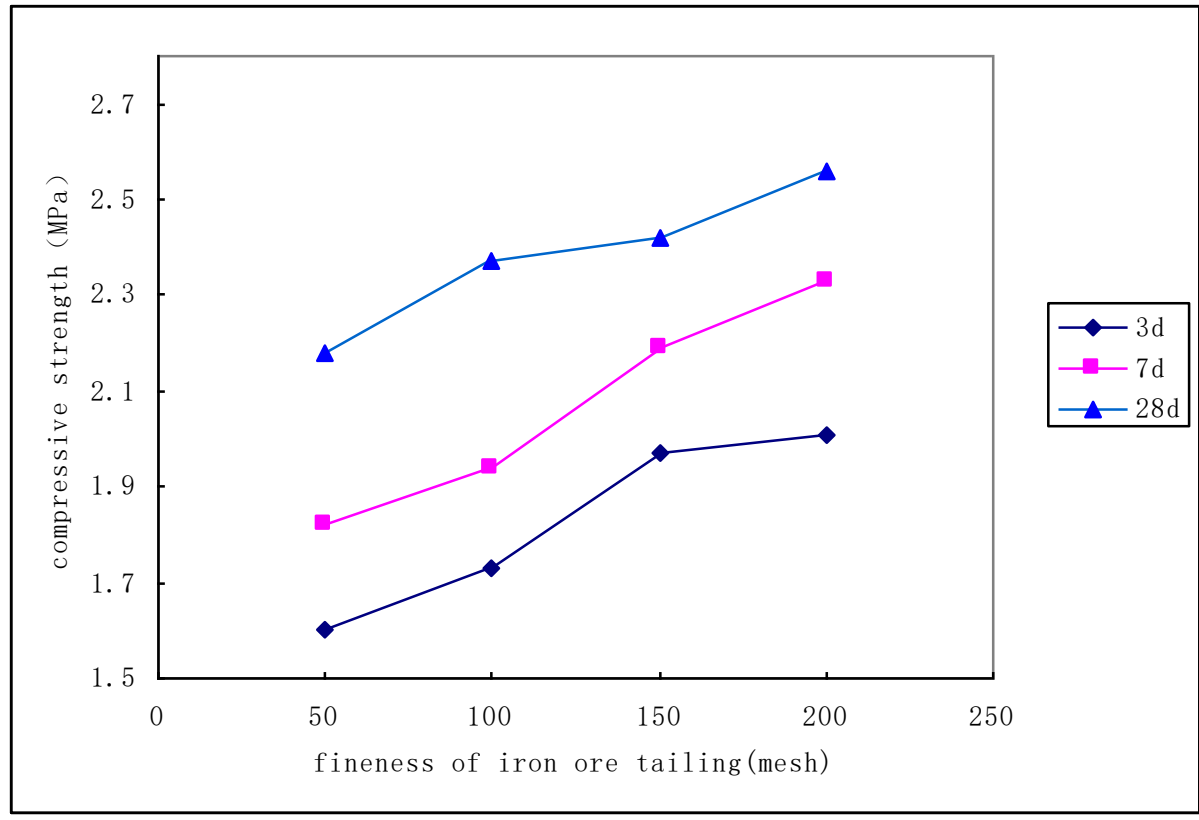

Figure 2 Influence of fineness of iron ore tailing on compressive strength of AAFC

Result are described in Table 5 and Figure 2 the compressive strength of alkali-activated slag foamed concrete increases gradually as the fineness increases of iron ore tailing When the fineness of iron ore tailing is 200 mesh, 28 days compressive strength of alkali-activated slag foamed concrete(apparent density is $700 \mathrm{Kg} / \mathrm{m} 3$ ) can reached $2.56 \mathrm{MPa}$ in standard curing condition. 
Adding of Specific Surface Area and Surface Energy of iron ore tailing because of the increases of fineness. It make iron ore tailing particles distribute more uniform and join tightly with the Alkali-activated Slag Foamed concrete.

\section{Conclusions}

(1)The compressive strength of alkali-activated slag foamed concrete increases on account of the hydration reaction is in process with prolonging curing time and adding apparent density.

(2) Too little or too much powder from iron ore tailing will reduce the compressive strength of alkali activated slag concrete, when powders from iron ore tailing achieving optimal amount, the compression strength of alkali-activated slag foamed concrete will be obviously improved.

(3)The compressive strength of alkali-activated slag foamed concrete increases gradually as the fineness increases of iron ore tailing

(4)When the fineness of iron ore tailing is 200 mesh, proportion reached $35 \%, 28$ days compressive strength of alkali-activated slag foamed concrete(apparent density is $500 \mathrm{Kg} / \mathrm{m} 3$ ) can reached $2.56 \mathrm{MPa}$ in standard curing condition. It can satisfy the requirement of wall materials at present.

\section{Acknowledgement:}

This research reported herein was supported by the Project of National Key Technology R\&D Program in the 12th Five Year Plan of China under grant No. 2013BAJ15B03 .

\section{References}

[1] Liu Guang yan:Study on the Properties of Alkali-activated Slag and Fly-ash Concrete . Fujian Architecture \& ConstrucionU , Vol. 32-33 (2008), p. 124.

[2] Chen You zhi:Prospects of Developing Alkali-activated Slag Cement and Concrete . Housing Materials \& Applications, Vol. 11-13 (1996).

[3] Zhang Zhi qiang, Zhou Dong liang and Li Fu gang: Selection of retarder of alkali activated slag cement. Concrete, Vol. 63-64 (2008), p. 226.

[4] Pan Zhi hua, Chen Lin and Li Dong xu: Study on the foamed concrete with high performance. Gypsum and Cement for Building, Vol. 1-4 (2002). 